\title{
Association between transported Asian dust and outdoor fungal concentration during winter in a rural area of western Japan
}

Kyoko Iwata ${ }^{1,2}$, Masanari Watanabe ${ }^{1 *}$, Jun Kurai ${ }^{1}$, Naoto Burioka ${ }^{3}$, Sachiko Nakamoto ${ }^{3}$, Degejirihu Hantan ${ }^{1}$ and Eiji Shimizu ${ }^{1}$

\begin{abstract}
Background: Recently, Asian dust (AD) has become a serious health problem and several studies have clearly proven that AD can aggravate asthma. However, it remains unclear as to which components of AD have a strong effect on the asthma exacerbation caused by AD exposure. Outdoor fungi can increase emergency department visits and hospitalization for asthma exacerbation and can aggravate asthma symptoms. Therefore, this study was aimed at investigating the relationship between $A D$ and outdoor fungi and determining the potential of fungi to cause airborne particulate matter (PM)-related inflammatory responses.

Methods: Airborne PM was collected each day from January 26, 2015 to February 27, 2015. Daily levels of outdoor fungi-associated PM were calculated using a culture-based method. Production of cytokines such as interleukin (IL)-6, IL-8, and tumor necrosis factor (TNF)-a was assessed in THP1 cells stimulated by the collected airborne PM each day.

Results: Daily levels of AD particles were assessed using Light Detection and Ranging and did not correlate with outdoor fungi $(r=-0.17, P=0.94)$. There was also no association between outdoor fungi and the daily production of IL-6 $(r=0.16, P=0.37)$, IL-8 $(r=0.19, P=0.30)$, or TNF-a induced by collected PM $(r=0.07, P=0$. 70). However, the daily levels of $A D$ particles were significantly associated with IL-6 $(r=0.91, P<0.0001)$, IL-8 $(r=0.64, P=0.0004)$, and TNF-a $(r=0.72, P<0.0001)$ production.

Conclusion: $A D$ did not increase the acute levels of outdoor fungi and outdoor fungi did not affect the cytokine production induced by airborne PM. These results suggest that outdoor fungi do not have any detectable effect on the asthma exacerbation caused by AD exposure.
\end{abstract}

Keywords: Airborne particulate matter, Asian dust, Cytokine production, Light detection and ranging, Outdoor fungi

\section{Background}

A large emission of sand dust in East Asia is referred to as Asian dust (AD), which originates mostly in the deserts of Central Asia, China, and Mongolia. AD is driven across the Korean Peninsula to Japan by prevailing westerly winds and provokes a yellow fog often in late winter and early spring [1]. A growing number of studies in

\footnotetext{
* Correspondence: watanabm@grape.med.tottori-u.ac.jp

'Department of Respiratory Medicine and Rheumatology, Faculty of

Medicine, Tottori University, Tottori, Japan

Full list of author information is available at the end of the article
}

epidemiology, toxicology, and other related fields have indicated that $\mathrm{AD}$ is closely related to the incidence of human diseases and mortality rate [2-7]. AD is also reported to increase the risk of exacerbation of asthma [8-13].

$\mathrm{AD}$ is composed of not only natural materials (soil components) but also anthropogenic particles such as sulfate oxide and nitrate oxide derived from fossil-fuel power stations and motor vehicles $[14,15]$. Although $\mathrm{AD}$ has been suggested to exert allergic and toxic effects, it remains uncertain as to which components of $\mathrm{AD}$ are associated with the exacerbation of asthma. Several studies 
have reported that outdoor fungi can increase emergency department visits and hospitalization for asthma exacerbation and can aggravate asthma symptoms [16-18]. AD has also been shown to carry microbial agents [19] and a few studies have reported increases in the abundance of several fungal taxa during heavy AD days [20-22]. Therefore, the fungi included in $\mathrm{AD}$ may constitute one of the causes for the exacerbation of asthma caused by AD.

Airway epithelial cells and inflammatory cells are the first to be exposed to airborne particulate matter (PM) such as AD particles. These cells are known to release a multitude of biochemical compounds including proinflammatory cytokines such as interleukin (IL)-6, IL-8, and tumor necrosis factor (TNF) $-\alpha$ in response to PM exposure [23]. Various components of PM can influence the subsequent pro-inflammatory cytokine response [24], with the inflammatory potential of PM being heterogeneous depending on the city and season [25-28]. Several studies have shown that these heterogeneous inflammatory responses may be partly attributed to the elemental composition of $\mathrm{AD}[25,26,29]$. However, the effects of fungi in airborne PM on the inflammatory response remain unclear.

Our previous study showed that exposure to outdoor fungi was associated with pulmonary dysfunction in children [30]. However, the relationship between fungi and $\mathrm{AD}$ has not been extensively studied in Japan, and the components having strong effects on the asthma exacerbation caused by $\mathrm{AD}$ exposure have not been identified. Therefore, this study was aimed at investigating the relationship between the quantity of outdoor fungi and $\mathrm{AD}$, because fungi associated with airborne PM may have a marked effect on asthma exacerbation caused by $\mathrm{AD}$ exposure. In the present study, we also evaluated the effects of fungi in airborne PM on inflammatory responses induced by airborne PM.

\section{Methods}

\section{Air pollutant levels}

The level of suspended particulate matter (SPM) is monitored at multiple locations throughout Japan by the Japanese Ministry of the Environment. Data for SPM collected in Matsue City were used in the present analysis. Light Detection and Ranging (LIDAR) systems can measure the levels of sand dust particles moving from East Asia to Japan, which can be used to identify non-spherical dust particles and spherical particles using laser light of two wavelengths within a height of $<1 \mathrm{~km}$ above the ground level [31-33]. LIDAR systems measure the levels of nonspherical dust particles such as AD particles at 15-min intervals, and the daily levels are determined based on the median value of 96 measurements collected over a 24-h period from the midnight of one day to the midnight of the next day. LIDAR data from Matsue City from 120 to
$150 \mathrm{~m}$ above the ground, which is the minimum altitude required by LIDAR systems, was obtained from the Japanese Ministry of the Environment. However, the definition of a heavy AD day using LIDAR measurements has not been established. According to a previous study by Ueda et al., a moderate Asian dust storm (ADS) day can be defined as a daily (24-h) average of $0.066 \mathrm{AD}$ particles (non-spherical particles) per kilometer, and a heavy ADS day would show a daily average of $0.105 \mathrm{AD}$ particles per kilometer [33]. Therefore, when the level of AD particles exceeds $0.06 \mathrm{~km}^{-1}$, it would be defined as a heavy ADS day.

\section{Calculation of the daily level of fungi-associated PM}

From January 26, 2015, to February 27, 2015, the daily level of outdoor fungi-associated airborne PM was assessed in Matsue city, the capital city of the Shimane Prefecture in southwest Japan. Matsue city has a population of approximately 200,000 inhabitants and covers a geographical area of $530.2 \mathrm{~km}^{2}$. Total suspended particles were collected on a $20 \times 25 \mathrm{~cm}$ quartz filter (2500QATUP; Tokyo Dylec, Tokyo, Japan) at a flow rate of $1000 \mathrm{~L} /$ min using a high-volume air sampler (HV-1000R; Shibata, Tokyo, Japan) for $23 \mathrm{~h}$ from 7 AM to 6 AM the following day. Before sampling, in order to relieve endotoxins from filters, the filters were sterilized by dry heat at $240{ }^{\circ} \mathrm{C}$ for $30 \mathrm{~min}$. After sampling, the 4- $\mathrm{cm}^{2}$ filter was detached and extracted with $4 \mathrm{~mL}$ distilled deionized water. The daily level of outdoor fungi-associated airborne PM was calculated using the culture-based method [34, 35]. To culture fungi among the collected total suspended particles, $500 \mu \mathrm{L}$ out of the $4 \mathrm{~mL}$ of filter extract was spread on Sabouraud agar in a 90-mm diameter dish. After 5 days of culture at $28{ }^{\circ} \mathrm{C}$, the growing colonies were counted and the mean value of five dishes was calculated. The daily levels of outdoor fungi-associated PM were expressed as colony forming units per cubic meter of air $\left(\mathrm{CFU} / \mathrm{m}^{3}\right)$.

\section{Cell culture and measurement of IL-6, IL-8, and TNF- $\alpha$ release}

After resection, the 4- $\mathrm{cm}^{2}$ filters used for fungal culture were extracted with $4 \mathrm{~mL}$ endotoxin-free distilled deionized water (sterile endotoxin-free water; Wako Pure Chemicals, Osaka, Japan) using an ultrasonic apparatus (BRANSONIC2800; Emerson Japan, Atsugi, Japan) for $60 \mathrm{~min}$. These extraction liquids were filtered through 10$\mu \mathrm{m}$ filters (pluriStrainer $10 \mu \mathrm{m}$; pluriSelect, Leipzig, Germany) to remove PM with sizes $>10 \mu \mathrm{m}$. $\mathrm{PM}<10 \mu \mathrm{m}$ in diameter dissolved in the solution, which was then sterilized at $121{ }^{\circ} \mathrm{C}$ for $30 \mathrm{~min}$ in an autoclave (Tomy SX-300; Tomy, Tokyo, Japan) and stored in a freezer at $-70{ }^{\circ} \mathrm{C}$ to prevent the growth of bacteria and fungi.

THP1 (ATCC ${ }^{\circ}$ TIB-202 ${ }^{\text {mim}}$ ) human monocyte cell lines were cultured in Roswell Park Memorial Institute 
medium 1640 containing 10\% (v/v) fetal bovine serum, $0.05 \mathrm{mM}$ 2-mercaptoethanol, $100 \mathrm{U} / \mathrm{mL}$ penicillin, $100 \mu \mathrm{g} / \mathrm{mL}$ streptomycin, and $0.5 \mu \mathrm{g} / \mathrm{mL}$ amphotericin B at $37{ }^{\circ} \mathrm{C}$ and $5 \% \mathrm{CO}_{2}$ in a humidified cell culture incubator. For the negative control, the THP1 cells $\left(1 \times 10^{5}\right.$ cells $/ 450 \mu \mathrm{L} /$ tube) were exposed to solvent only for $24 \mathrm{~h}$ at $37{ }^{\circ} \mathrm{C}$ in an endotoxin-free tube (pirotube; Seikagaku, Tokyo, Japan), and the test cells were added to $50 \mu \mathrm{L}$ of each PM solution. After exposure, the culture supernatants were removed and first centrifuged at $250 \times g$ to remove the floating cells and then at $2,500 \times g$ to remove the remaining particles. The final supernatants were stored at $-70{ }^{\circ} \mathrm{C}$. The concentrations of IL-6, IL-8, and TNF- $\alpha$ in the cells were then measured using an enzyme-linked immunosorbent assay (ELISA) kit for IL6, IL-8, and TNF- $\alpha$ (R\&D Systems, Minneapolis, MN, USA) according to the manufacturer's protocols with endotoxin-free 96-well plates (Toxipet plateLP; Seikagaku, Tokyo, Japan). The samples were run in triplicate and read using an automated ELISA reader (Model 680, Bio-Rad, Philadelphia, PA, USA). The production levels of IL-6, IL-8, and TNF- $\alpha$ induced by each dissolving solution were defined as the daily IL-6, IL-8, and TNF- $\alpha$ levels induced by SPM.

\section{Statistical analysis}

The associations between fungal levels and the daily levels of SPM, AD particles, IL-6, IL-8, and TNF- $\alpha$ were assessed by linear regression analysis. Data analyses were performed using SPSS statistical software (Japanese ver. 21.0 for Windows; IBM Japan, Tokyo, Japan). All Pvalues were two-sided with a significance level of 0.05 .

\section{Results}

\section{Levels of SPM, AD particles, and outdoor fungi}

Figure 1a shows the daily levels of SPM and AD particles from January 26 to February 27, 2015. The data of AD particles were lacked in eight days: January 26, January 30, and February 1, 5, 8, 9, 13, and 17. The mean levels of SPM and AD particles were $12.7 \pm 9.0 \mu \mathrm{g} / \mathrm{m}^{3}$ and $0.02 \pm 0.03 \mathrm{~km}^{-1}$, respectively. The daily levels of the AD particles exceeded the $0.6 \mathrm{~km}^{-1}$ threshold on February 23,24 , and $25\left(0.10,0.13\right.$, and $0.9 \mathrm{~km}^{-1}$, respectively); these three days were therefore determined as heavy ADS days. Figure 1b shows the significant correlation between the daily levels of SPM and AD particles.

Figure 2a presents the daily levels of outdoor fungi; the average level was $73.5 \pm 44.7 \mathrm{CFU} / \mathrm{m}^{3}$ from January 26 to February 27, 2015. The levels of fungi on the heavy ADS days were as follows: $72.2 \mathrm{CFU} / \mathrm{m}^{3}$ on February 23, 93.1 CFU $/ \mathrm{m}^{3}$ on February 24, and $77.1 \mathrm{CFU} / \mathrm{m}^{3}$ on February 25. The daily levels of AD particles exceeded the mean level on two of these three heavy ADS days. There was no correlation

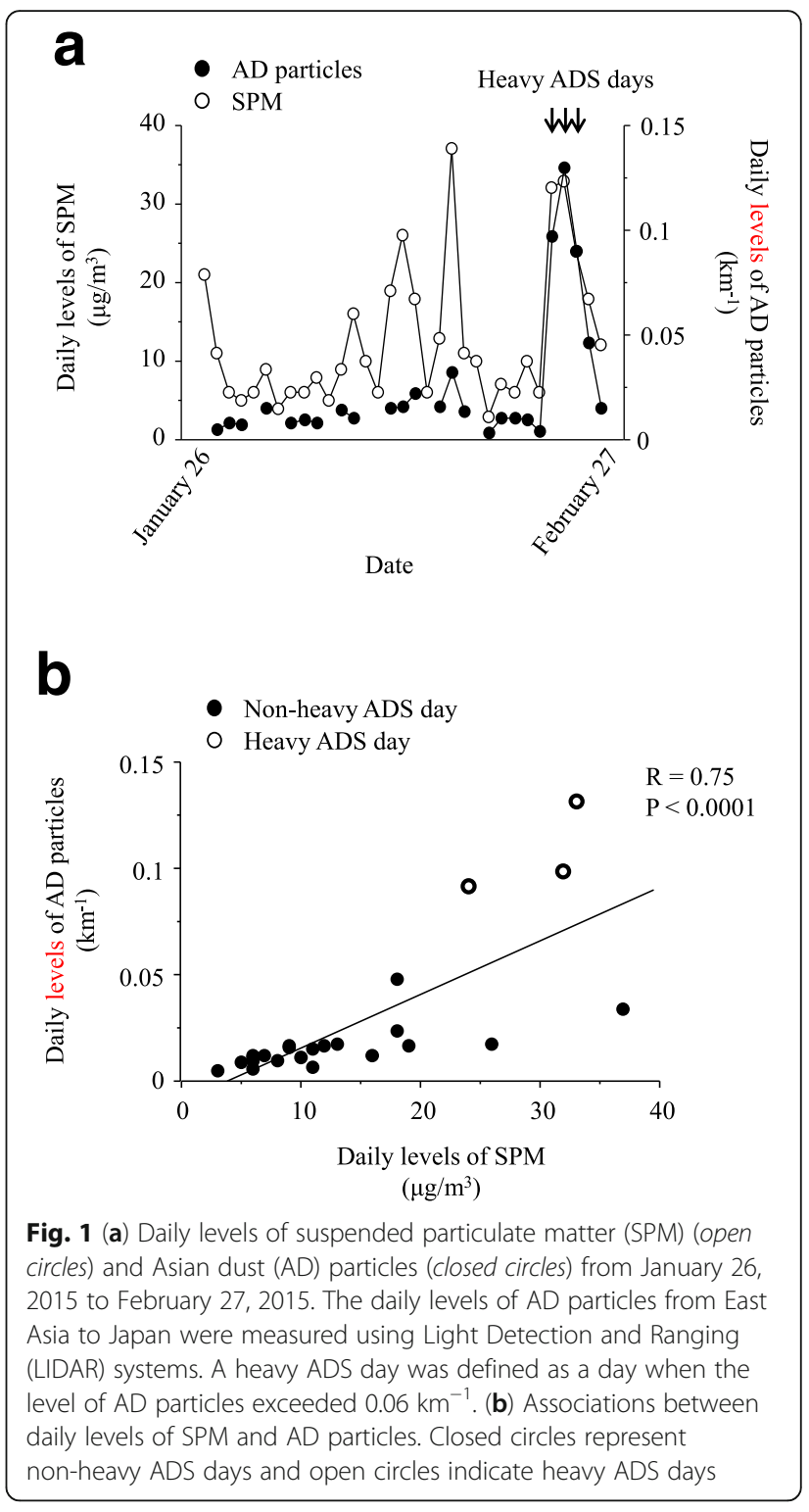

between the daily levels of SPM, AD particles, and outdoor fungi (Fig. 2b and c).

\section{Associations between pro-inflammatory cytokine produc- tion, outdoor fungi, and AD particles}

The $\mathrm{pH}$ levels of all the collected airborne PMdissolving solutions ranged from 7.6 to 8.1. After stimulation by the collected airborne PM, the viability of the THP1 cells exceeded 95\% in all the samples, as assessed using a trypan blue-exclusion test. However, we did not find any association between the daily IL-6, IL-8, and TNF- $\alpha$ levels induced by SPM and the daily levels of outdoor fungi (Fig. 3a, b, and c). In contrast, there were significant relationships between the daily IL-6, IL-8, and TNF- $\alpha$ levels induced by SPM, and the daily levels of AD particles (Fig. 4). 
a

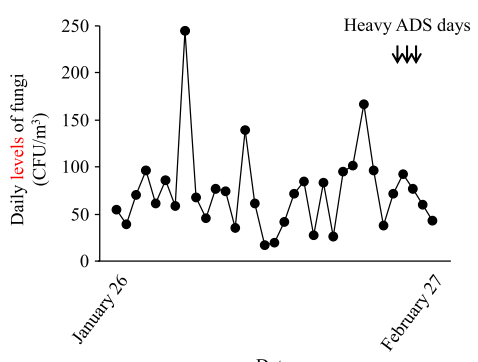

Date b $\quad$ i Non-heary ADS day

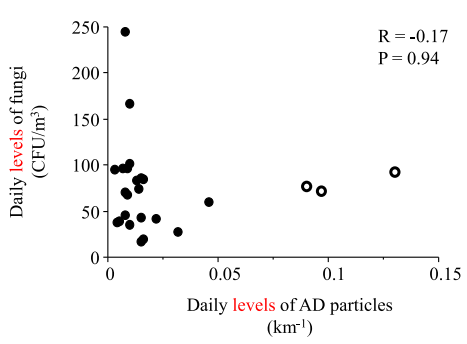

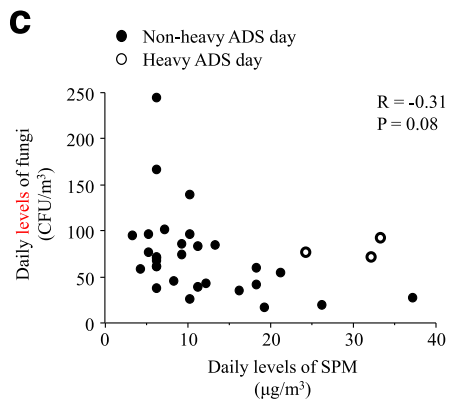

Fig. 2 (a) Daily levels of fungi associated with airborne particulate matter from January 26 to February 27, 2015. (b) Associations between daily levels of fungi and Asian dust (AD) particles. (c) Associations between daily levels of fungi and suspended particulate matter (SPM). Closed circles represent non-heavy ADS days and open circles indicate heavy ADS days (b, $\mathbf{c})$

\section{a}

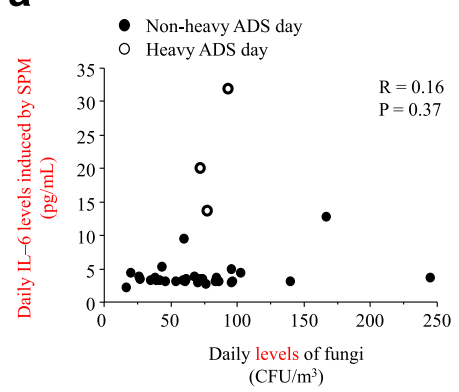

b

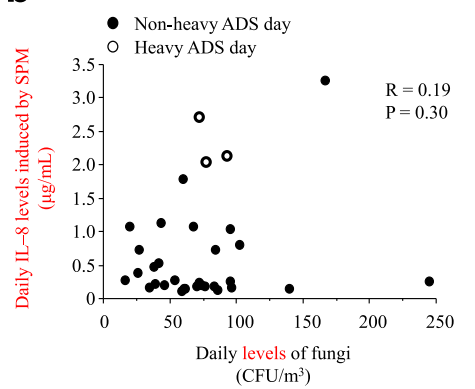

C

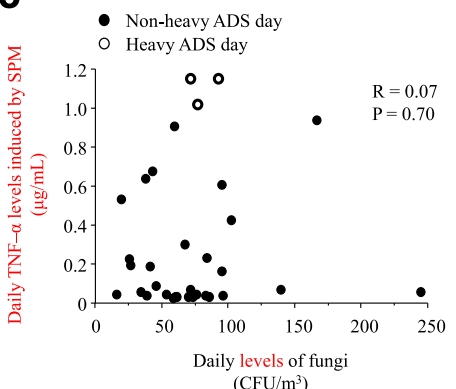

Fig. 3 Associations between daily levels of fungi and (a) interleukin (IL)-6, (b) IL-8, and (c) tumor necrosis factor (TNF)-a levels induced by suspended particulate matter (SPM). Closed circles represent non-heavy ADS days and open circle indicate heavy ADS days 

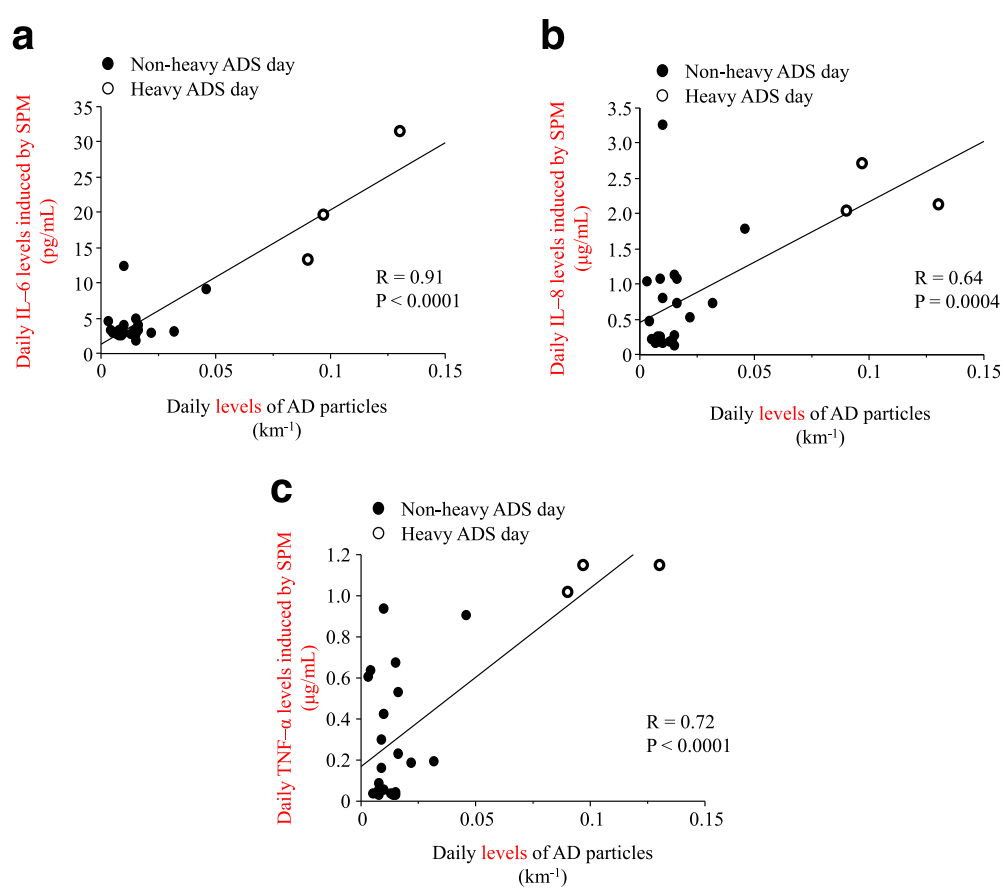

Fig. 4 Associations between daily levels of Asian dust (AD) particles and (a) interleukin (IL)-6, (b) IL-8, and (c) tumor necrosis factor (TNF)-a levels induced by suspended particulate matter (SPM). Closed circles represent non-heavy ADS days and open circles indicate heavy ADS days

\section{Discussion}

Although little is known regarding the association between outdoor fungi and AD in Japan, studies conducted in South Korea and Taiwan have shown that AD can contribute to the amount and characteristics of outdoor fungi $[20-22,36]$. In these studies, the researchers used the levels of SPM or particulate matter smaller than $10 \mu \mathrm{m}$ in aerodynamic diameter $\left(\mathrm{PM}_{10}\right)$ to determine a heavy ADS day. Similarly, most of the research on AD often involved the use of SPM or $\mathrm{PM}_{10}$ to determine a heavy ADS day. Recently, it has become possible to measure the daily quantity of AD particles using LIDAR systems. According to LIDAR data, small quantities of AD particles arrive in Japan mostly from February to May [31, 32]. To the best of our knowledge, the present study is among the first to use LIDAR data to study the association between the quantity of outdoor fungi and $\mathrm{AD}$.

In the present study, we did not find any association between the daily levels of outdoor fungi and AD particles. Similarly, there was no relationship between the daily levels of outdoor fungi and SPM. We were unable to analyze the differences in the amount of outdoor fungi between heavy ADS days and non-heavy ADS days, because there were only three heavy ADS days during the study period. This also compromised our ability to identify the association between the levels of outdoor fungi and $\mathrm{AD}$ particles. The effects of $\mathrm{AD}$ on the amount of outdoor fungi vary between studies, even when the studies are conducted in the same country. For example, in Taiwan, Ho et al. found that heavy levels of $\mathrm{AD}$ could increase the concentrations of outdoor fungi [20]. They also showed a significant positive association between the levels of outdoor fungi and SPM. However, Wu et al. were unable to find the same effect in Taiwan [21]. Furthermore, in another study, Alghamdi et al. found an association with inverse PM2.5 concentrations (1/PM2.5) and outdoor fungi [37], which may indicate that the fungal levels do not correlate with PM mass levels. Alghamdi et al. also suggested that wind speed positively correlates with the levels of bacteria and fungi-associated airborne PM [37]. Therefore, in order to positively define the effects of $\mathrm{AD}$ on the levels of outdoor fungi, further studies need to be conducted taking wind into consideration.

Considerable evidence indicating an association between the exacerbation of asthma and AD has been accumulated [8-13]. However, the mechanism underlying the ADinduced exacerbation of asthma remains unclear. Several studies have shown that outdoor fungi were associated with an increase of emergency department visits, hospitalizations, and aggravation of asthma symptoms in patients with asthma [16-18]. However, according to the results of the present study, heavy exposure to outdoor fungi does not represent a likely cause for the exacerbation of asthma caused by exposure to $\mathrm{AD}$. 
A multitude of in vitro studies have focused on the effects of airborne PM on pro-inflammatory cytokine production to understand the mechanisms underlying the adverse health effects caused by exposure to airborne PM [23]. However, researchers have found it difficult to identify the components of airborne PM that have the most effect on cytokine production. Our previous study showed that the effects of airborne PM exposure on pulmonary function in schoolchildren differ with the type and source of the PM [38]. In contrast, in the present study, we were unable to find any association between outdoor fungi and the production of cytokines such as IL-6, IL-8, and TNF- $\alpha$ in THP1 cells exposed to airborne PM. However, we found significant relationships between the production of cytokines such as IL-6, IL-8, and TNF- $\alpha$, and the level of AD particles. Based on this result, we believe that exposure to $\mathrm{AD}$ particles might exacerbate asthma through the aggravation of airway inflammation. However, outdoor fungi were not found to play a role in the association between inflammatory response and $\mathrm{AD}$ exposure.

In order to investigate the underlying mechanism by which airborne PM provokes an adverse effect on health, a multitude of in vitro studies have been performed focusing on cytokine production. In a review by Mitschik et al. on the in vitro effects of airborne PM on cytokine production [23], TNF- $\alpha$ was revealed as the cytokine most often selected for revealing details about the harmful effects of airborne PM on health, followed by IL- 8 and IL- 6 . This result underscores the proposed key roles of TNF- $\alpha$, IL- 8 , and IL-6 in the inflammatory responses to airborne PM. Therefore, in the present study, TNF- $\alpha$, IL- 8 , and IL-6 were selected to examine the relationship between fungi in airborne PM on the inflammatory responses induced by airborne PM. However, in 27 out of 33 days during study period, the levels of IL- 6 were below $5 \mathrm{pg} / \mathrm{mL}$. Compared to TNF- $\alpha$ and IL-8, the sensitivity was thus insufficient to study the effect of PM on IL-6 production owing to the small amount of collected PM in this study.

To evaluate the inflammatory responses induced by collected SPM in the present study, we were desirous of using dendritic cells (DCs), which populate the airways and play important roles in antigen presentation, cytokine production, and the initiation of inflammation. In particular, inhalation substances contact DCs in the airway subsequent to initial contact with airway epithelial cells. However, the culture procedures necessary to generate DCs from human monocytes are costly and time consuming. Alternatively, human monocyte cell lines have been explored as potential surrogates for human DCs [39], with THP1 cells being reported to exhibit potential as DC surrogates [40]. Therefore, the present study investigated the inflammatory responses induced by collected SPM using the THP1 cell line.
There are several limitations of this study. First, outdoor gaseous and particulate data generally and largely depend on season, weather, and region. The present study was not conducted across multiple locations, seasons, and years. Therefore, the results of the present study were unable to confirm the reproducibility of the association between $\mathrm{AD}$ and outdoor fungal concentration. Second, the culture-based method used for calculating outdoor fungi was unable to detect all existing outdoor fungi, because several strains of fungi cannot grow on Sabouraud agar culture. Therefore, it is reasonable to conclude that we underestimated the concentrations of fungi. Third, the present study did not include investigation of the characteristics of the fungi. Fourth, the daily amount of airborne PM was very small compared to the filter weight. Therefore, measurement of the quantity of daily collected airborne PM lacked precision. This resulted in an inability to calculate the daily levels of IL-6, IL-8, and TNF- $\alpha$ to obtain a unit quantity of collected airborne PM.

\section{Conclusion}

In this study, we used a LIDAR system to determine the daily levels of SPM, AD particles, and outdoor fungi. No association was identified between the daily levels of outdoor fungi and $\mathrm{AD}$ particles. We also did not find any evidence of an increase in the levels of outdoor fungi caused by $\mathrm{AD}$ arriving from East Asia to Japan. Additionally, outdoor fungi did not appear to affect the cytokine production induced by exposure to airborne PM. However, we did find significant relationships between the production of IL-6, IL-8, and TNF- $\alpha$ and the level of $\mathrm{AD}$ particles. These results suggest that outdoor fungi are unlikely to exert any noticeable effect on the asthma exacerbation caused by AD exposure.

\section{Abbreviations}

AD: Asian dust; ADS: Asian dust storm; CFU/m³ : Colony forming units per cubic meter of air; ELISA: Enzyme-linked immunosorbent assay; IL: Interleukin; LIDAR: Light Detection and Ranging; PM: Particulate matter; SPM: Suspended particulate matter; TNF-a: Tumor necrosis factor-a

\section{Acknowledgements}

We would like to thank Atsushi Shimizu (National Institute for Environmental Studies) for providing LIDAR data. We would like to thank Editage (www.editage.jp) for English-language editing.

\section{Funding}

This research was supported by the Environmental Research and Technology Development Fund (5-1453) of the Japanese Ministry of the Environment and Tottori prefecture

Availability of data and materials Not applicable.

Authors' contributions

$\mathrm{KL}, \mathrm{MW}, \mathrm{JK}$, and ES conceived the study. KI, MW, JK, and ES designed the study. $\mathrm{Kl}, \mathrm{MW}$, and JK wrote the manuscript. Kl, MW, JK, NB, SN, and DH 
contributed to data collection. $\mathrm{Kl}, \mathrm{MW}, \mathrm{JK}, \mathrm{NB}, \mathrm{SN}$, and $\mathrm{DH}$ performed the laboratory work. Kl, MW, and JK performed the statistical analysis and interpretation of the results. Kl, MW, and JK contributed to critical revision of important intellectual content. All authors read and approved the final manuscript.

\section{Competing interests}

The authors declare no conflict of interest.

\section{Consent for publication}

All authors read and approved the final manuscript.

\section{Ethics approval and consent to participate}

Not applicable.

\section{Publisher's Note}

Springer Nature remains neutral with regard to jurisdictional claims in published maps and institutional affiliations.

\section{Author details}

${ }^{1}$ Department of Respiratory Medicine and Rheumatology, Faculty of Medicine, Tottori University, Tottori, Japan. ${ }^{2}$ Mio Fertility Clinic, Reproductive Centre, Tottori, Japan. ${ }^{3}$ Division of School of Health Science, Department of Pathobiological Science and Technology, Tottori University Faculty of Medicine, Tottori, Japan.

Received: 16 January 2017 Accepted: 11 May 2017

Published online: 01 July 2017

\section{References}

1. Tanaka TY, Chiba M. A numerical study of the contributions of dust source regions to the global dust budget. Glob Planet Chang. 2006;52:88-104.

2. Hashizume M, Ueda K, Nishiwaki Y, Michikawa T, Onozuka D. Health effects of Asian dust events: a review of the literature. Nihon Eiseigaku Zasshi. 2010;65:413-21.

3. Chen YS, Sheen PC, Chen ER, Liu YK, Wu TN, Yang CY. Effects of Asian dust storm events on daily mortality in Taipei, Taiwan. Environ Res. 2004;95:151-5.

4. Bell ML, Levy JK, Lin Z. The effect of sandstorms and air pollution on cause-specific hospital admissions in Taipei, Taiwan. Occup Environ Med. 2008;65:104-11.

5. Chan CC, Chuang KJ, Chen WJ, Chang WT, Lee CT, Peng CM. Increasing cardiopulmonary emergency visits by long-range transported Asian dust storms in Taiwan. Environ Res. 2008;106:393-400.

6. Kwon HJ, Cho SH, Chun Y, Lagarde F, Pershagen G. Effects of the Asian dust events on daily mortality in Seoul, Korea. Environ Res. 2002;90:1-5.

7. Lai LW, Cheng WL. The impact of air quality on respiratory admissions during Asian dust storm periods. Int J Environ Health Res. 2008;18:429-50.

8. Kanatani KT, Ito I, Al-Delaimy WK, Adachi Y, Mathews WC, Ramsdell JW. Toyama Asian Desert Dust and Asthma Study Team. Desert-dust exposure is associated with increased risk of asthma hospitalization in children. Am J Respir Crit Care Med. 2010;182:1475-81.

9. Yoo Y, Choung JT, Yu J, Kim DK, Koh YY. Acute effects of Asian dust events on respiratory symptoms and peak expiratory flow in children with mild asthma. J Korean Med Sci. 2008;23:66-71.

10. Ding YP, Yao HX, Tang XL, He HW, Shi HF, Lin L, Li M, Chen S, Chen J, Wang HJ. An epidemiology study of bronchial asthma in the Li ethnic group in China. Asian Pac J Trop Med. 2012:5:157-61.

11. Watanabe M, Yamasaki A, Burioka N, Kurai J, Yoneda K, Yoshida A, Igishi T, Fukuoka Y, Nakamoto M, Takeuchi H, Suyama H, Tatsukawa T, Chikumi H, Matsumoto S, Sako T, Hasegawa Y, Okazaki R, Horasaki K, Shmizu E. Correlation of Asian dust storms with worsening of symptoms for patients with asthma in western Japan. Allergol Int. 2011;60:267-75.

12. Watanabe $M$, Igishi T, Burioka N, Yamasaki A, Kurai J, Takeuchi H, Sako T, Yoshida A, Yoneda K, Fukuoka Y, Nakamoto M, Hasegawa Y, Chikumi H, Matsumoto S, Minato S, Horasaki K, Shimizu E. Pollen augments the influence of desert dust on symptoms of adult asthma patients. Allergol Int. 2011;60:517-24.

13. Park JW, Lim YH, Kyung SY, An CH, Lee SP, Jeong SH, Ju YS. Effects of ambient particulate matter on peak expiratory flow rates and respiratory symptoms of asthmatics during Asian dust periods in Korea. Respirology. 2005:10:470-6.
14. Noh Y, Müller D, Shin SK, Shin D, Kim YJ. Vertically-resolved profiles of mass concentrations and particle backscatter coefficients of Asian dust plumes derived from lidar observations of silicon dioxide. Chemosphere. 2016;143:24-31.

15. Go YY, Park MK, Kwon JY, Seo YR, Chae SW, Song JJ. Microarray Analysis of Gene Expression Alteration in Human Middle Ear Epithelial Cells Induced by Asian Sand Dust. Clin Exp Otorhinolaryngol. 2015;8:345-53.

16. Tham R, Dharmage SC, Taylor PE, Katelaris CH, Vicendese D, Abramson MJ, Erbas B. Outdoor fungi and child asthma health service attendances. Pediatr Allergy Immunol. 2014;25:439-49.

17. Pongracic JA, O'Connor GT, Muilenberg ML, Vaughn B, Gold DR, Kattan M, Morgan WJ, Gruchalla RS, Smartt E, Mitchell HE. Differential effects of outdoor versus indoor fungal spores on asthma morbidity in inner-city children. J Allergy Clin Immunol. 2010;125:593-9.

18. Inal A, Karakoc GB, Altintas DU, Pinar M, Ceter T, Yilmaz M, Kendirli SG. Effect of outdoor fungus concentrations on symptom severity of children with asthma and/or rhinitis monosensitized to molds. Asian Pac J Allergy Immunol. 2008:26:11-7.

19. Chen PS, Tsai FT, Lin CK, Yang CY, Chan CC, Young CY, Lee CH. Ambient influenza and avian influenza virus during dust storm days and background days. Environ Health Perspect. 2010;118:1211-6.

20. $\mathrm{Ho} \mathrm{H}$, Rao CY, Hsu HH, Chiu YS, Liu CM, Chao HJ. Characteristics and determinants of ambient fungal spores in Hualien, Taiwan. Atomos Environ. 2005:39:5839-50.

21. Wu PC, Tsai JC, Li FC, Lung SC, Su HJ. Increased levels of ambient fungal spores in Taiwan are associated with dust events from China. Atomos Environ. 2004:38:4879-86.

22. Yeo HG, Kim JH. SPM and fungal spores in the ambient air of west Korea during the Asian dust (Yellow sand) period. Atomos Environ. 2002;36:5437-42.

23. Mitschik S, Schierl R, Nowak D, Jörres RA. Effects of particulate matter on cytokine production in vitro: a comparative analysis of published studies. Inhal Toxicol. 2008;20:399-414

24. Ovrevik J, Låg M, Holme JA, Schwarze PE, Refsnes M. Cytokine and chemokine expression patterns in lung epithelial cells exposed to components characteristic of particulate air pollution. Toxicology. 2009;259:46-53.

25. Kumar RK, Shadie AM, Bucknall MP, Rutlidge H, Garthwaite L, Herbert C, Halliburton B, Parsons KS, Wark PA. Differential injurious effects of ambient and traffic-derived particulate matter on airway epithelial cells. Respirology. 2015;20:73-9.

26. Hetland RB, Cassee FR, Låg M, Refsnes M, Dybing E, Schwarze PE. Cytokine release from alveolar macrophages exposed to ambient particulate matter: heterogeneity in relation to size, city and season. Part Fibre Toxicol. 2005:2:4

27. Jalava PI, Hirvonen MR, Sillanpää M, Pennanen AS, Happo MS, Hillamo R, Cassee FR, Gerlofs-Nijland M, Borm PJ, Schins RP, Janssen NA, Salonen RO. Associations of urban air particulate composition with inflammatory and cytotoxic responses in RAW 246.7 cell line. Inhal Toxicol. 2009:21:994-1006.

28. Salonen $\mathrm{RO}$, Hälinen Al, Pennanen AS, Hirvonen MR, Sillanpää M, Hillamo R, Shi T, Borm P, Sandell E, Koskentalo T, Aarnio P. Chemical and in vitro toxicologic characterization of wintertime and springtime urban-air particles with an aerodynamic diameter below 10 microm in Helsinki. Scand J Work Environ Health. 2004;30:80-90.

29. Becker S, Dailey LA, Soukup JM, Grambow SC, Devlin RB, Huang YC. Seasonal variations in air pollution particle-induced inflammatory mediator release and oxidative stress. Environ Health Perspect. 2005;113:1032-8.

30. Watanabe M, Noma H, Kurai J, Hantan D, Burioka N, Nakamoto S, Sano H, Taniguchi J, Shimizu E. Association between Outdoor Fungal Concentrations during Winter and Pulmonary Function in Children with and without Asthma. Int J Environ Res Public Health. 2016;13:E452.

31. Sugimoto $\mathrm{N}$, Lee $\mathrm{CH}$. Characteristics of dust aerosols inferred from lidar depolarization measurements at two wavelengths. Appl Opt. 2006;45:7468-74.

32. Sugimoto N, Matsui I, Shimizu A. Lidar network observations of tropospheric aerosols. Proc SPIE. 2008;23:783-9.

33. Ueda K, Shimizu A, Inoue K. Exposure assessment by Light Detection and Ranging for Asian dust aerosol in epidemiological studies to investigate its health effects. Earosoru Kenkyu. 2014:29:230-6.

34. Alghamdi MA, Shamy M, Redal MA, Khoder M, Awad AH, Elserougy S Microorganisms associated particulate matter: a preliminary study. Sci Total Environ. 2014:479-480:109-16.

35. Lee T, Grinshpun SA, Martuzevicius D, Adhikari A, Crawford CM, Luo J, Reponen T. Relationship between indoor and outdoor bio-aerosols 
collected with a button inhalable aerosol sampler in urban homes. Indoor Air. 2006;16:37-47.

36. Chao HJ, Chan CC, Rao CY, Lee CT, Chuang YC, Chiu YH, Hsu HH, Wu YH. The effects of transported Asian dust on the composition and concentration of ambient fungi in Taiwan. Int J Biometeorol. 2012;56:211-9.

37. Alghamdi MA, Shamy M, Redal MA, Khoder M, Awad AH, Elserougy S.

Microorganisms associated particulate matter: a preliminary study. Sci Total Environ. 2014;479-480:109-16.

38. Watanabe M, Noma H, Kurai J, Sano H, Hantan D, Ueki M, Kitano H, Shimizu E. A panel study of airborne particulate matter composition versus concentration: Potential for inflammatory response and impaired pulmonary function in children. Allergol Int. 2017;66:52-8.

39. Takahashi T, Kimura Y, Saito R, Nakajima Y, Ohmiya Y, Yamasaki K, Aiba S. An in vitro test to screen skin sensitizers using a stable THP-1-derived IL-8 reporter cell line, THP-G8. Toxicol Sci. 2011;124:359-69.

40. Ashikaga T, Sakaguchi H, Sono S, Kosaka N, Ishikawa M, Nukada Y, Miyazawa M, Ito Y, Nishiyama N, Itagaki H. A comparative evaluation of in vitro skin sensitisation tests: the human cell-line activation test (h-CLAT) versus the local lymph node assay (LLNA). Altern Lab Anim. 2010;38:275-84.

Submit your next manuscript to BioMed Central and we will help you at every step:

- We accept pre-submission inquiries

- Our selector tool helps you to find the most relevant journal

- We provide round the clock customer support

- Convenient online submission

- Thorough peer review

- Inclusion in PubMed and all major indexing services

- Maximum visibility for your research

Submit your manuscript at www.biomedcentral.com/submit

) Biomed Central 